\title{
Interpersonal Conflict and Knowledge Hiding Behavior: Mediating Role of Perceived Competition
}

\author{
Joko Prayetno ${ }^{a}$, Muhammad Rasyid Abdillah ${ }^{\text {a, }}$ \\ a'Department of Management, Graduate Program, Universitas Lancang Kuning, Indonesia.
}

\begin{tabular}{|c|c|}
\hline ABSTRACT & ARTICLE HISTORY \\
\hline $\begin{array}{l}\text { The background of this research is based on the importance of measuring } \\
\text { the conflicts that occur in a company that caused knowledge hiding } \\
\text { behavior. The purpose of this study was to determine the extent of the } \\
\text { relationship between interpersonal conflict and knowledge hiding behavior } \\
\text { by mediating perceived competition. By using samples from pharmaceutical } \\
\text { companies, there are often visible or invisible interpersonal conflicts that } \\
\text { caused subordinates to engage in knowledge hiding behavior. Furthermore, } \\
\text { perceived competition also mediates the psychological process underlying } \\
\text { the link between interpersonal conflict and knowledge hiding behavior. } \\
\text { With the results of the existing research, it is hoped that it will become a } \\
\text { picture for supervisors to prevent counterproductive knowledge behavior, } \\
\text { such as knowledge hiding through reducing the intensity of the } \\
\text { interpersonal conflict. }\end{array}$ & $\begin{array}{l}\text { KEYWORDS } \\
\text { Interpersonal Conflict, } \\
\text { Knowledge Hiding Behavior } \\
\text { and Mediating Role }\end{array}$ \\
\hline
\end{tabular}

\section{Introduction}

From ancient times until now, most living socially will bring goodness to humans themselves rather than living alone. With humans having socialized and grouped, then formed an effort to achieve the goal. This in turn makes humans as creatures who achieve goals in one container or organization or company to achieve the same goal. Of course, this will bring even better benefits considering that there are many people in one organization that will bring ideas and solutions to every problem.

Then if the company consists of several people, there will be a new problem called conflict. According to Antonius, et al (2002), conflict is an action of one party that results in blocking, inhibiting, or disturbing another party where this can occur between community groups or in interpersonal relationships. Obviously with this understanding, conflict can occur between individuals in the organization.

Meanwhile, in interpersonal conflict according to Donohue and Kolt (1992) defines interpersonal conflict as a situation in which individuals who are interdependent, express differences (either manifest or latent) in an effort to meet the needs and desires of each and they experience interference from each other to achieve their goals. This is inseparable from the nature of the company which makes employee achievements and attitudes the basis for 
assessment in career paths and salary increases. Of course, this is natural and the company has made this the right basis for the assessment.

Previous research has found that interpersonal conflict can encourage employees to engage in knowledge-hiding behavior in the Turkish context (Semerci, 2019). Meanwhile, research that explains the relationship between interpersonal conflict and knowledge-hiding behavior in the context of companies in Indonesia has yet to be found. Especially in pharmaceutical companies. Likewise, the research discusses the mechanisms that underlie the relationship is unexplored. Thus, research that seeks to explain the mechanism of this relationship in the Indonesian context is still very much needed. Based on these research problems, this study poses two main questions, namely does interpersonal conflict affect the behavior of hiding knowledge? If so, does perceived competition mediate interpersonal conflict relationships and knowledge-hiding behavior?

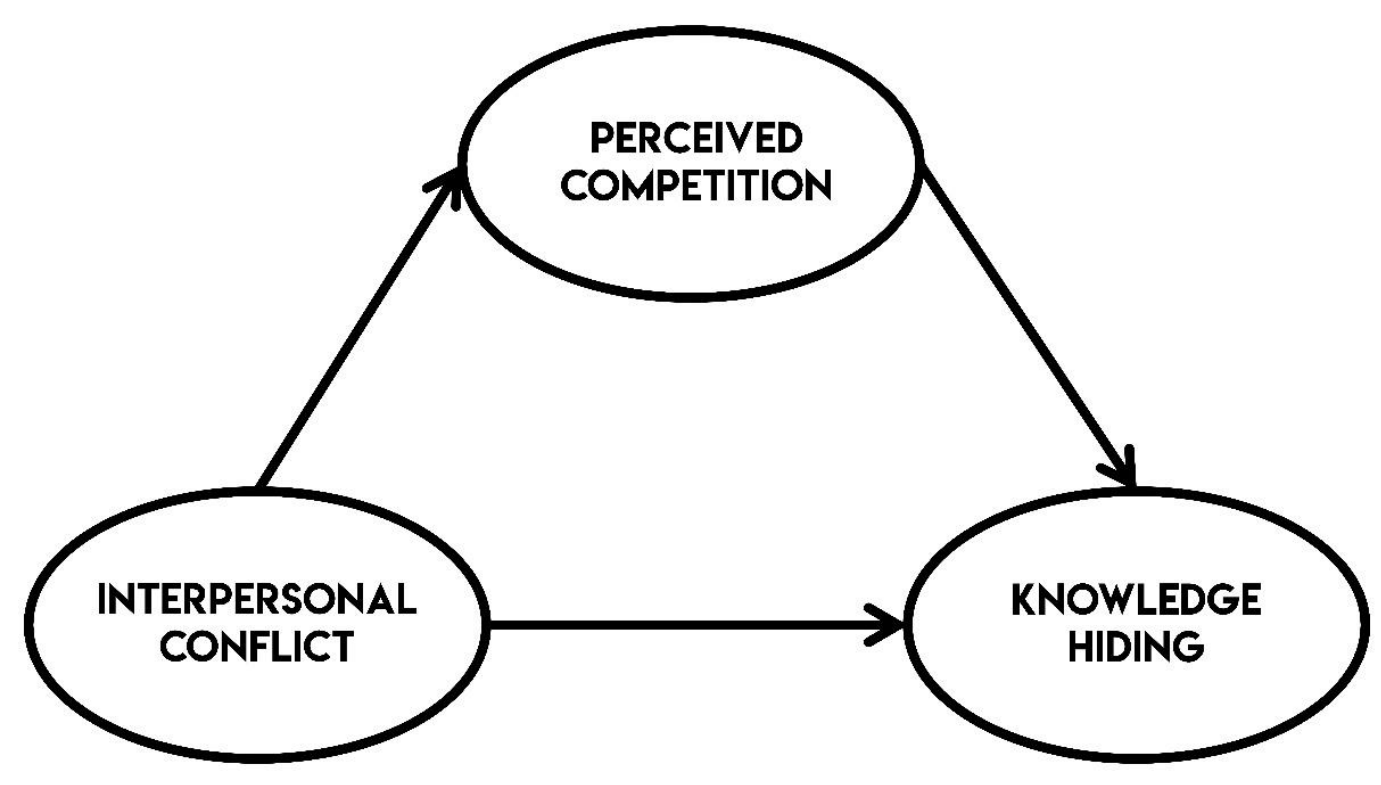

Figure 1. Research Framework

One of the conflicts that often occur can cause subordinates' engagement in knowledge hiding behavior. A competition that often arises when individuals want to show their capacity and also want to show individual achievements. According to Bernstein, Rjkoy, Srull, \& Wickens said that competition occurs when individuals try to achieve goals for themselves by beating others while according to Acks and Krupat (1988) gives the notion of competition as an attempt to fight or exceed other people or an organization. 
This is more often the case in pharmaceutical marketing, where they gain knowledge on their own in the field. For a pharmaceutical company that is indeed a marketing person, it is called Medical representatife (medrep). In Pekanbaru alone, there are 200 MEDREPs consisting of 40 companies, either PMA (Foreign Companies) or PMDN (Domestic Companies). Some things that become a problem are in 1 office some colleagues will hide knowledge, whether it's information or the right technique in generating demand in hospitals or doctors. Things like this happen because the mederep really want a promotion and salary increase without any peer competitors. This is a barometer of attitude to always provide knowledge when needed by colleagues. For those in the MEDREP, who will indeed work based on the knowledge or information obtained to be processed, it becomes a strategy in creating demand. Then the right knowledge base will really help his work.

The phenomenon of knowledge hiding behavior is certainly very detrimental to the organization. This behavior can hinder the flow of information within the company (Serenko \& Bontis, 2016) and reduce creativity (Černe et al., 2014). In addition, this behavior also increases organizational and interpersonal deviant behavior (Singh, 2019). Thus, research that explains the phenomenon of knowledge-hiding behavior is still very much needed and recommended by scientists in the field of organizational behavior and management studies (Connelly et al., 2019).

\section{Theoretical support}

\section{Social Exchange Theory (SET)}

The theory of social exchange was initiated by Blau (1964). This theory states that employees tend to develop high-quality relationships based on who they interact with, how they interact, and how they experience it (Blau, 1964). When employees are treated properly by their leaders and co-workers (social environment), they will think about reciprocal relationships with their leaders or co-workers in terms of social exchanges that are more important than economic exchanges (Cropanzano \& Mitchell, 2005).

\section{Interpersonal Conflict}

Interpersonal conflict is a disagreement that results from a personal incompatibility regarding individual beliefs, values, or personality between a person and another person in the workplace (Babalola et al., 2018). Interpersonal conflict can interfere with a person's professional activities, interactions and several other behaviors within the organization (Semerci, 2019).

\section{Felt competition}

Competition is born from the personality of someone who wants something that is also desired by other individuals. This of course makes competition as a medium to achieve goals. Competition is generally defined as "mutually exclusive goal attainment" (Kohn, 1992). 


\section{Knowledge Hiding Behavior}

Knowledge hiding behavior is one of several types of counterproductive knowledge behavior (Serenko \& Bontis, 2016). This behavior refers to the efforts of an individual to deliberately withhold or withhold knowledge requested by others (Connelly et al., 2012). Knowledge hiding behavior is more complex than other counterproductive knowledge behaviors. This behavior is intentional because members of the organization are consciously involved in this behavior.

\section{Research method}

\section{Explanatory Study Research}

This research is an explanatory study, namely research that aims to explain why an event occurs and to build, expand, elaborate or test theory (Neuman, 2011). This study aims to explain the mechanism that underlies the relationship between interpersonal conflict and the behavior of hiding knowledge based on theory. In other words, this research is an explanatory research that uses quantitative methods to test hypotheses empirically.

In social research, especially in the field of management, quantitative method is a research method rooted in the positivist social science approach which "emphasizes discovering causal law, careful empirical observations and value-free research" (Neuman, 2014, p. 97). This study then utilizes a cross-sectional survey in collecting research data to test the formulated hypotheses.

\section{Results}

\section{Analysis of SEM-PLS}

The hypotheses that have been developed in this study were tested using SEM-PLS analysis using WarpPLS 5.0 software. The analysis consists of several stages. First, this study conducted a model fit test which aims to determine whether the model built in this study is good (Wetzels, Odekerken-Schröder, \& Van Oppen, 2009). Second, this study analyzes the measurement model by validating the measurement scale of each variable (Chin, 2010).

Validation on the measurement scale of each variable is discriminant validity, convergent validity, and reliability (Hair, Sarstedt, Hopkins, \& Kuppelwieser, 2014). Third, this study considers the "common method variance" test which aims to see whether the data in this study produces a "common method bias" problem or not (Podsakoff, MacKenzie, \& Podsakoff, 2012). Finally, the current research conducts structural model analysis which aims to test all the hypotheses that have been proposed.

One of the advantages of SEM-PLS analysis is that it is able to analyze models with a limited sample size ranging from 35-50 (Solihin \& Ratmono, 2013). Using a limited sample, this analysis "can achieve quite high statistical power" (p. 11). Likewise, if the population is $(>90)$, 
then this analysis "can improve the accuracy and consistency of the SEM-PLS estimation results" (p. 11). Based on the assumption of using SEM-PLS, this study plans to collect research samples above 90 samples.

\section{Discussions}

\section{Structural Model Test Results}

Evaluation of the structural model aims to test all the hypotheses that have been proposed.

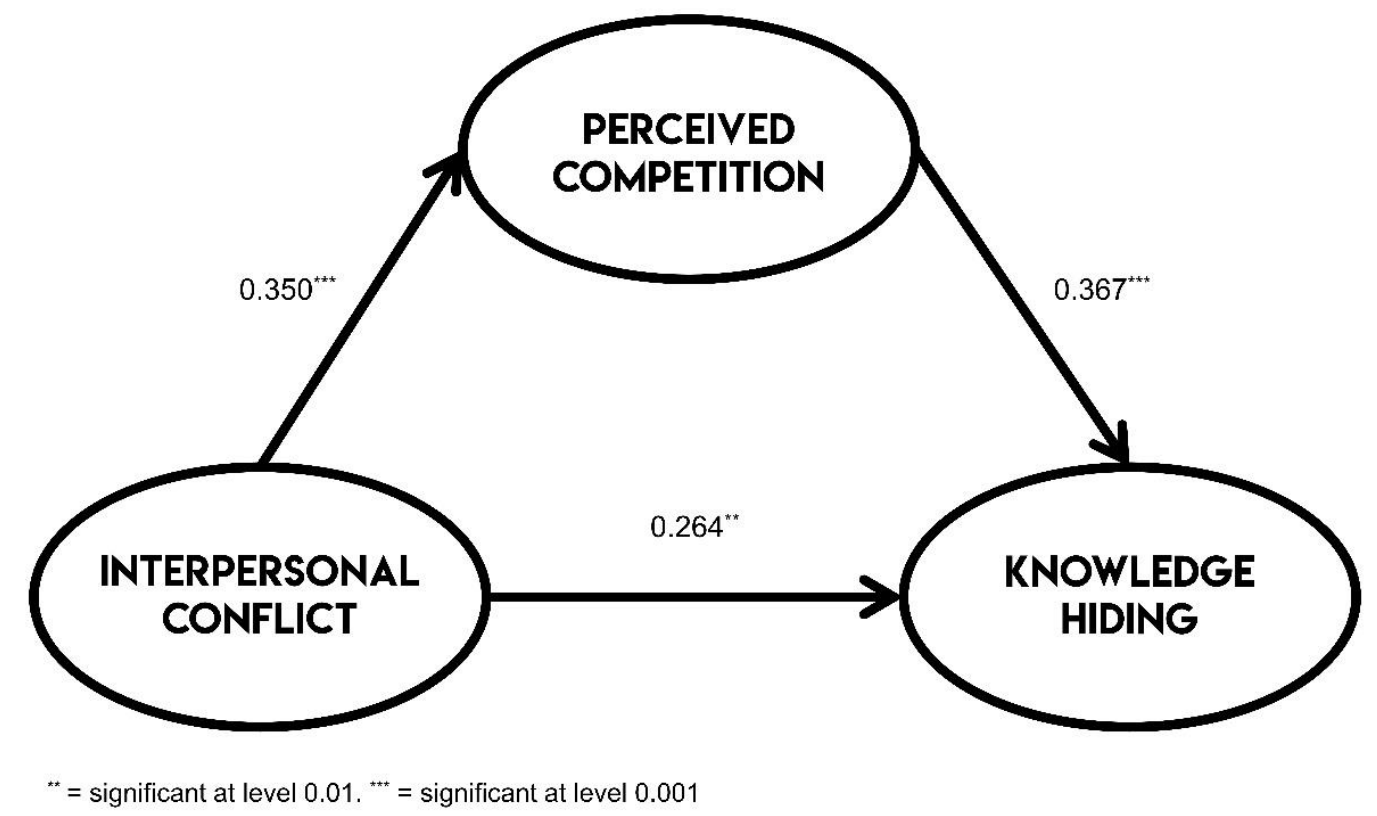

Figure 2. Hypothesis Testing Results.

\section{Indirect Influence}

The first hypothesis (H1) predicts that Interpersonal Conflict has a positive effect on Perceived Competition. The results in table and Figure 2 show that this hypothesis is statistically supported $(\beta=0.350, \mathrm{p}<0.001)$. The table shows that the Interpersonal Conflict variable positively causes Perceived Competition.

The second hypothesis (H2) predicts that perceived competition has a positive effect on knowledge hiding behavior. The results show that this hypothesis is statistically supported ( $\beta$ $=0.367, \mathrm{p}<0.001)$. Furthermore, the third hypothesis $(\mathrm{H} 3)$ predicts that perceived competition mediates the effect of interpersonal conflict on hiding knowledge. The results show that this hypothesis is statistically supported $(\beta=0.128, \mathrm{p}<0.001)$.

The table shows that the perceived competition variable significantly mediates interpersonal conflict towards hiding knowledge. The table also shows that when the mediating variable (perceived competition) is included in the model, the value of interpersonal conflict on 
knowledge-hiding behavior decreases from 0.264 to insignificant. These results indicate that the perceived competition variable in this study fully mediates the effect of interpersonal conflict on the behavior of hiding knowledge.

\section{Conclusion}

From the results described previously, it can be concluded that interpersonal conflict has a positive effect on perceived competition, perceived competition has a positive effect on knowledge hiding behavior, and perceived competition mediates the effect of interpersonal conflict on hiding knowledge.

\section{Disclosure statement}

No potential conflict of interest was reported by the authors.

\section{References}

Abdillah, M.R. (2020). Effects of Altruistic Leadership on Knowledge Hiding among Subordinates: Testing a Dual Mediation Mechanism. (Doctoral dissertation, Da-Yeh University, Taiwan). Retrieved from: https://hdl.handle.net/11296/g3e8ug

Abdillah, M. R., Wu, W., \& Anita, R. (2020). Can altruistic leadership prevent knowledge-hiding behaviour? Testing dual mediation mechanisms. Knowledge Management Research \& Practice. https://doi.org/10.1080/14778238.2020.1776171

Babalola, M. T., Stouten, J., Euwema, M. C., \& Ovadje, F. (2018). The relation between ethical leadership and workplace conflicts: The mediating role of employee resolution efficacy. Journal of Management, 44(5), 2037-2063.

Bernstein, D. (2018). Essentials of psychology. USA: Cengage Learning.

Blau, P. M. (1964). Exchange and power in social life. New York, NY: John Wiley.

Černe, M., Nerstad, C. G., Dysvik, A., \& Škerlavaj, M. (2014). What goes around comes around: Knowledge hiding, perceived motivational climate, and creativity. Academy of Management Journal, 57(1), 172-192.

Connelly, C. E., Zweig, D., Webster, J., \& Trougakos, J. P. (2012). Knowledge hiding in organizations. Journal of organizational behavior, 33(1), 64-88.

Connelly, C. E., \& Zweig, D. (2015). How perpetrators and targets construe knowledge hiding in organizations. European Journal of Work and Organizational Psychology, 24(3), 479-489.

Connelly, C. E., Černe, M., Dysvik, A., \& Škerlavaj, M. (2019). Understanding knowledge hiding in organizations. Journal of Organizational Behavior, 40(7), 779-782.

Cropanzano, R., \& Mitchell, M. S. (2005). Social exchange theory: An interdisciplinary review. Journal of management, 31(6), 874-900.

Cropanzano, R., Dasborough, M. T., \& Weiss, H. M. (2017). Affective events and the development of leadermember exchange. Academy of Management Review, 42(2), 233-258.

Dalkir, K. (2017). Knowledge management in theory and practice. Cambridge, MA: MIT press.

Esses, V. M., Jackson, L. M., Dovidio, J. F., \& Hodson, G. (2005). Instrumental relations among groups: Group competition, conflict, and prejudice. On the nature of prejudice: Fifty years after Allport, 227-243.

Kohn, A. (1992). No contest: The case against competition. Boston: Houghton Mifflin Harcourt.

O'Neill, T. A., Allen, N. J., \& Hastings, S. E. (2013). Examining the "pros" and "cons" of team con flict: A teamlevel meta-analysis of task, relationship, and process conflict. Human Performance, 26(3), 236-260.

Peng, H. (2013). Why and when do people hide knowledge?. Journal of knowledge management, 17(3), 398-415

Robbins, S. P., \& Judge, T. (2018). Essentials of organizational behavior. Essex, England: Pearson Education Limited. 
Joko Prayetno, Interpersonal Conflict and Knowledge...

Semerci, A. B. (2019). Examination of knowledge hiding with conflict, competition and personal values. International Journal of Conflict Management, 30(1), 111-131.

Serenko, A., \& Bontis, N. (2016). Understanding counterproductive knowledge behavior: antecedents and consequences of intra-organizational knowledge hiding. Journal of knowledge management, 20(6), 11991224.

Shaukat, R., Yousaf, A., \& Sanders, K. (2017). Examining the linkages between relationship conflict, performance and turnover intentions. International Journal of Conflict Management, 24(1), 4-23

Singh, S. K. (2019). Territoriality, task performance, and workplace deviance: Empirical evidence on role of knowledge hiding. Journal of Business Research, 97, 10-19.

Walumbwa, F. O., Mayer, D. M., Wang, P., Wang, H., Workman, K., \& Christensen, A. L. (2011). Linking ethical leadership to employee performance: The roles of leader-member exchange, self-efficacy, and organizational identification. Organizational behavior and human decision processes, 115(2), 204-213. 